\title{
Improving South African third graders' reading skills: Lessons learnt from the use of Guided Reading approach
}

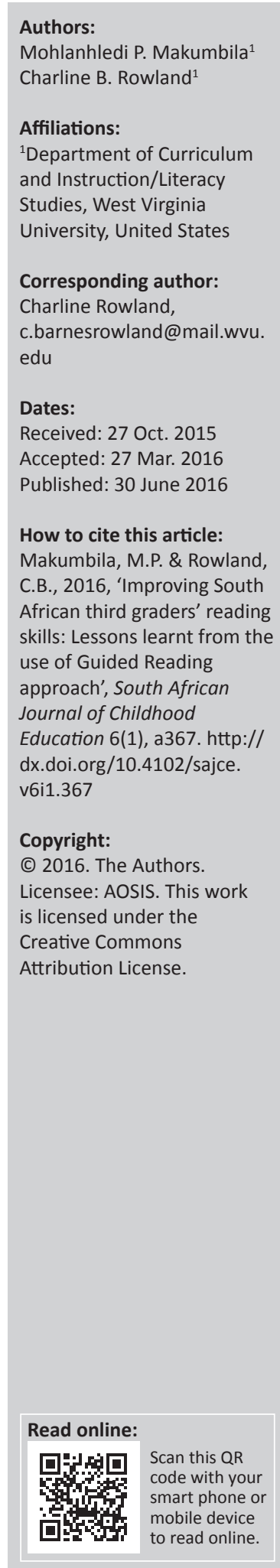

This professional development project, known as Literacy Leadership Project, enabled four Foundation Phase teachers in South Africa to implement the Guided Reading approach. Developed by American researchers Fountas and Pinnell (1996), Guided Reading helps elementary students strengthen their phonemic awareness, vocabulary, reading comprehension and fluency in small group activities. Over an 8-month period, lessons learnt came from data collected from this professional development included workshop activities, classroom observations, teachers' group discussions and students' artefacts. Results indicated improvement in students' literacy engagement and motivation because of the use of levelled books, oral reading and group activities.

\section{Introduction}

For 6 years, I was an Elementary Literacy Support Educator at Aregorogeng Primary School (the school's name is a pseudonym) in South Africa. There, I assisted students who had learning difficulties as well as teachers who had problems teaching these students in their classroom from Foundation Phase (FP) (grades R-3) through Intermediate Phase (grades 4-7). The school enrolled 1549 student in grades R-7. There were 58 teachers who were all highly qualified in their respective subjects. The school taught in three native languages: $77 \%$ was Sepedi, $24 \%$ was XiTsonga and $9 \%$ IsiZulu. According to South African educational system policy for FP, students were taught in their native language. English was introduced from second grade as a subject. But when students entered in Intermediate Phase, they switched from their native language and English became the medium of instruction in all content areas.

Literacy instruction was allocated $40 \%$ during the FP. Within this time, teachers were expected to teach the foundation strategies that would assist students to understand their reading text and provide students with a variety of reading, speaking and writing opportunities in all content areas. Whereas in the Intermediate Phase students were expected to use strategies learnt in the FP and integrate them in a variety of reading texts for a different reasons such as summarising, predicting, questioning, interpreting and searching for information (South African Department of Education 2003). The South African Department of Education' Systemic Evaluation results for 2007 indicated that the average achievement of third graders' reading comprehension skills was $36 \%$. So, Aregorogeng Primary School assigned a baseline assessment to grades 3-6 to assess their reading literacy, and the results found that 540 students from those grades have been determined to be at risk in their reading, speaking and writing performance.

As an Elementary Literacy Support Educator teacher, I first met with the literacy specialist to further discuss these data and possible instructional solutions. Later, I met the Head of Department (HoD) for the FP and four third-grade teachers to address the literacy needs of the their student population, including being exposed to a diversity of reading materials at an early age in order to be good readers (South African Department of Education 2003; National Institute of Child Health and Human Development [NICHD] 2000).

The literacy specialist, $\mathrm{HoD}$ and myself thought of the reading principles that stated that teachers need to build their reading instruction from student's background and teach the individual to read and write independently (Heilman, Blair \& Rupley 2002). According to these principles, teachers need to work hard on planning and structuring their classrooms, develop reading instruction and activities to model and collaborate and provide more opportunities for students every day. Teachers also need to expose students to different-levelled books and cultural books in 
their classroom in order to become independent readers (Heilman et al. 2002). Furthermore, the South African Teacher's Handbook (2007:54) for teaching reading in the early grades reported that to promote literacy in classrooms, literacy specialists and support educators can 'build groups of teachers at a cluster level who have acquired strong instructional knowledge in reading, provide coach and model effective reading strategies'. Therefore, the goal of this literacy leadership project was to provide support to select third-grade teachers of how to differentiate the reading instruction in their classroom that would help students increase their vocabulary and reading comprehension.

An invitation went out to all third-grade teachers at the Aregorogeng Primary School. During the group discussion meeting, teachers were advised to practice effective strategies everyday with students to help increase students' reading skills that would make them independent readers. However, a third-grade teacher raised this question based on her overcrowded classroom: How do I schedule effective reading instruction daily in order to engage, motivate, and increase students' reading in this situation?' This question led me to implement the Guided Reading approach, which was suggested by the literacy specialist.

Research on Guided Reading (Fountas \& Pinnell 1996) found that the approach could provide teachers and students with more reading opportunities in the classroom that would help students become independent readers. It was also an element already adapted by most of the South African literacy programmes such as Literacy Learning Program for FP and Languages Learning Program for Intermediate Phase. Secondly, Guided Reading has a variety of teaching strategies that can be used by any teacher to increase students' vocabulary and comprehension skills, which was the main focus of this literacy leadership project. Thirdly, students at third-grade were about to switch their native language instruction into English and it was necessary for them to be prepared to transfer the first learned language reading instruction skills into the process of reading instruction of their second language (English) at their early stage (Avalos et al. 2007). Finally, Fountas \& Pinnell (1996:21) identified Guided Reading as the most 'essential component of balanced literacy program' in which teachers support the students' learning by teaching strategies for processing text by allowing any teacher to differentiate instruction in order to meet the diverse needs of all age readers and comprehension strategies in the classroom through whole-group, small-group and individual activities. Students can work in small groups with the help of their teacher for 3-5 days per week for between 10 and 30 minutes in order to develop phonemic awareness, phonetic awareness, vocabulary, reading comprehension and fluency. To achieve this, a teacher models reading instruction to students on how to read, think, summarise or ask questions while the students can be encouraged to write their own stories and talk about them to other members of the groups. A teacher keeps on directing and supporting students with understanding difficult words or texts by building on the students' prior knowledge, discussing and revisiting the text or supporting the process through strategies based on students' mistakes. During Guided Reading, students can have an understanding of reading the text before, during and after the comprehension passage that can enable teachers to extend students' vocabulary development, knowledge and use of comprehension strategies (Fountas \& Pinnell 1996; Pressely 2000).

\section{Design of literacy leadership project}

This 8-month project included a professional development workshop, teacher discussion group and direct classroom observation. Four FP teachers volunteered to participate. The reading specialist and I introduced to these teachers core literacy teaching knowledge. I also went to the school library to checkout children's levelled books and I found out that the library did not have enough books for participating students. So I made enough copies of all the checked out books.

At our all-day professional development workshop, we taught the teachers the Guided Reading approach. Fountas and Pinnell (1996:4) suggested that teachers need to gain knowledge before for how to use the approach; therefore, in the group discussion we learnt that during Guided Reading:

(a) a teacher works with a small group; (b) children in the group are similar in their development of reading process and are able to read about the same level of text; (c) teachers introduce stories and assist children's reading in ways that help to develop independent reading strategies; (d) each child reads the whole text; (e) the emphasis is on reading increasingly challenging books over time, and (f) children are grouped and regrouped in a dynamic process that involves ongoing observation of meaning overrides.

We also reviewed a survey study about how to create these students' groups. It was suggested that successful teachers group students by four to six per group (Ford \& Opitz 2008).

All the original books I checked out from library were displayed on the tables at the front of the classroom together with the copies I made for each class. Teachers were advised to select and group them according to their students' reading levels. Fountas and Pinnell (1996) stated that teachers need to keep students engaged by selecting students' level books, modelling reading instruction during the process and continually observing, assessing and recording all individuals' progress. Therefore, I modelled all workshops' activities by selecting one common children's levelled book entitled 'Mufaro's Beautiful Daughters' by John Steptoe (1993). The book was selected because its story content related to students' environment and their culture, which I thought would help students' to better understand the context of the story, activities and instruction much easier.

Story Summary: Mufaro's Beautiful Daughters is an African tale. The two daughters were beautiful. Nyasha was beautiful inside and outside, meaning she was kind, caring and nice to every living thing, but the sister Manyara was beautiful outside only. She was mean, aggressive and angry all the time. 
Her intention was to be a queen and turn her sister Nyasha into her slave servant. One day a king invited all beautiful daughters from all the land to come before him so that he could choose a wife. On their way to the king's palace, the king presented himself to Manyara as a snake, a hungry dirty child and an old woman. Manyara behaved strangely towards them all. To Nyasha the king presented his kingdom, and she became the king's wife.

Books should be relevant to students' needs, challenging, familiar, and have to teach students certain strategies that could be applied in other content areas (Heilman et al. 2002).

I provided each teacher with a copy of the workshop's lesson plan so that they could follow all the activities that I would be doing. Because the selected book was big, at each group's table there were three copies, which meant that two students were sharing one copy. The lesson plan's activities were designed according to the three group levels accommodated in the classrooms. Using real students from one of the participating teachers' classrooms, I modelled how to introduce a new book by holding it up and asking questions about the cover. I walked through the book pages showing pictures as we predicted the story. At the back of the classroom, there was a chart of the map of Africa, and then I modelled to teachers how I could integrate the text with other content areas (i.e. location of the country where the story was taking place). Then I read aloud to them, requesting them to find new words and circle each word that was repeatedly used in the book. As the third step, I stopped and modelled how to ask questions from the story to see if the students understood. I also modelled using the new words identified page by page to summarise the story. At times, I stopped and modelled how to break words into simple parts. To make connections to all these reading areas - read aloud, vocabulary, comprehension - there were a variety of activities for all three groups because of the different reading abilities. Participants were given opportunities of rereading the story as a group, individually and in pairs and later I used the activity of finding the definitions of the new words identified by using the dictionary on each table. For comprehension, I asked one group to summarise the story and another group to discuss the relationship between 'Cinderella' and 'Mufaro's Beautiful Daughters' stories. As the last part of the workshop's lesson, students were given the opportunity for choosing the activity of their interest such as drawing and painting any facial expression on the mask, drawing a beautiful wedding dress for Nyasha or creating a wedding invitation card to any family or friends. From their interest activities, students were asked to write their own sentences or stories about their art which will be discussed at the end. But I first modelled drawing a picture on a chalkboard and then wrote a few sentences about it. While they were still busy, I also modelled how to provide support to struggling students by chunking and decoding large words by making students understand the sounds of letters represented, creating words and then reading aloud the new words. Teachers' feedback of the workshop was very positive.

\section{Observations and teachers' conference findings}

During the professional development workshop, the teachers and I agreed to use three different forms of reading assessment checklists for Developing, Transitional and Independent levels students (see Appendixes, A, B \& C). I also agreed to observe each classroom once a month, including having teacher conferences after each visit. The IsiZulu class had 38 while XiTsonga class had 34 students. With the two Sepedi classrooms, I scheduled 2-day observations every month because of the classes being overcrowded. Each of Sepedi classrooms had 40 students.

\section{Guided reading activities practiced}

During my observations, I noticed that all group reading sessions were provided with a variety of similar activities and copies of levelled books throughout the process. Teachers used reading aloud more often. They regularly asked questions at the beginning, middle and end of each reading when they read aloud to students. All four teachers used strategies summarising and predicting as they read the books aloud. The students even asked questions about the story and were also be able to retell main ideas from the story.

\section{Vocabulary activities practiced}

From IsiZulu and XiTsonga classes (two classrooms), students were instructed to read aloud in pairs to their peer members, while other group members listened, looked and underlined words that their peer members had problems with. I found this activity interesting because it was encouraging peer evaluation, discipline and competency. The activity was also providing a teacher with extra time to support struggling groups. Teachers used selected vocabulary words and encouraged students to re-write their own sentences. From two classrooms of Sepedi, teachers allowed students to practice the word-sorting activities in groups under noun, verb and adjective columns. The transitional and independent level groups were asked to identify, sort and read a range of common words from the text. Most of the time, teachers walked around listening to students reading in groups and providing support to groups that had problems recalling words automatically. They also modelled how to look for words in the dictionary, write the meaning, draw a picture on the side and create own sentences with the words. The teachers also allowed students to practice using vocabulary words to build their own short sentences, which were shared with other groups. Students were also given an opportunity to draw pictures next to the new word and write the name of the picture with their native language and then in English underneath.

\section{Comprehension practiced}

A lot of discussion activities were provided in all classes and independent level students were also helping one another in some activities while their teachers were still busy with struggling readers. One of the selected books was 'The Elephant's Child' by Rudyard Kipling (1986). 
Story Summary: The Elephant is extremely curious and is always asking questions of animals, and one day his curiosity directs him down to where the crocodile lives in Limpopo River. The crocodile snatches onto the elephant's very short nose and pulls until his trunk is stretched very long, and then the nose never returns back to its shape again.

Some of the students' families live near Limpopo River so I observed many of the boys talking about the dangerous spots of this river. Most guiding questions were used to develop students' comprehension, such as what did the elephants look like at the beginning? Why elephant child asked so many questions? Which animals helped the elephants to have trunks and how? Do you think that the elephant child would finally get the truth of its trunk? A lot of talking, predicting, questioning and summarising happened from this book. In all the classrooms, more opportunities for writing short stories, doing arts and show and tell were offered to build students' self-confidence. Some students were shy to talk about their stories or art in English but encouraging words from their teachers were always used to increase student's engagement and motivation. Teachers were always displaying students' work or arts on the bulletin board at the back of the classroom.

During my observations, I found that a majority of the students found the activities interesting and most of the students liked all the activities they were assigned to do. Every Friday afternoon for an hour, all four classrooms assembled together during Guided Reading period. Students talked about stories they wrote, read aloud books of their interest to other group members and read aloud vocabulary words and definitions they wrote in their wordbook.

\section{Data results and other findings}

The school principal was included in the last teacher meeting. The results were read from teachers' observations and reading assessment checklists for the three levels. At the beginning of this project, all Sepedi and XiTsonga classes had higher percentage of struggling students than IsiZulu classes. After implementing Guided Reading, the struggling students percentage dropped down to $11 \%, 13 \%$ and $10 \%$, respectively.

During Guided Reading period, teachers found that Independent level students were more effective than the other two groups in all activities for practicing vocabulary and comprehension. This group volunteered in telling their own stories during Guided Reading session and during breaks while playing with their friends outside classrooms. Teachers reported that these students increased their use of oral English language in their classrooms and liked to summarise paragraphs read from the books. Compared to Transitional and Developing level students, Independent level students attempted to use more vocabulary words learnt in their leisure writing and understood their meaning faster. From the Transitional level group, teachers found an average change because students' reading proficiency in identifying main ideas and answering questions in full sentences made them quickly move to the Independent level in both classrooms. Teachers also found that the Developing level students did not have sufficient confidence of reading aloud their levelled books to other groups. They did not show enough vocabulary words to participate in group discussion activities or attempt to use for their leisure writing stories. This group was also found mixing their native language with English when writing their own short stories or sentences. Yet, teachers reported a slow but steady change from Developing and Transitional level groups in all the classrooms (see Table 1).

\section{Other issues with Implementation of Guided Reading}

Based on observations and teacher conferences, I learnt that factors such as insufficient amount of levelled reading materials, inappropriate levelled reading materials, limited time highlighted by teachers and large classroom size played a role in limiting students from increasing their reading skills. These factors were also found in one recent research conducted in South Africa that evaluated Guided Reading in three primary schools in Western Cape (Kruizinga \& Nathanson 2010). The study found that teachers have neither adequate levelled reading materials to practice Guided Reading nor clear policy documents providing clarifications about the strategies to implement Guided Reading in their classrooms.

\section{Teachers and reading materials}

In all levelled reading materials used, teachers continued making reading copies for the entire process of the project and some of the books were even borrowed from lower grades to make this an effective project. Teachers also had trouble matching students' level books with their students because of a lack of training in using assessment tools. They wanted to learn more about reading strategies for the primary classroom. Teachers also had difficulty differentiating Guided Reading activities in their classrooms because of the physical, space, especially in two Sepedi classrooms where tables occupied so much space.

\begin{tabular}{lclcc} 
TABLE 1: Observation results data. & & \\
\hline Class & $\begin{array}{c}\text { Number of } \\
\text { students }\end{array}$ & Groups & $\begin{array}{c}\text { Results before } \\
\text { guided reading (\%) }\end{array}$ & $\begin{array}{c}\text { Results after } \\
\text { guided reading (\%) }\end{array}$ \\
\hline XiTsonga & 34 & (a) Independent & 56 & 67 \\
& & (b) Transitional & 29 & 23 \\
& & (c) Developing & 15 & 10 \\
IsiZulu & 38 & (a) Independent & 54 & 63 \\
& & (b) Transitional & 24 & 28 \\
& & (c) Developing & 12 & 9 \\
Sepedi A & 40 & (a) Independent & 47 & 61 \\
& & (b) Transitional & 33 & 26 \\
& & (c) Developing & 18 & 13 \\
Sepedi B & 40 & (a) Independent & 42 & 60 \\
& & (b) Transitional & 34 & 29 \\
& & (c) Developing & 24 & 11 \\
\hline
\end{tabular}

Source: Makumbila, M.P., 2012, Foundation Phase Observation Results Data 


\section{Time allocation for foreign language}

Because the main instruction in the FP was in students' native language in all content learning areas and English was taught as a subject for 35 minutes three times in a week, I found that not enough time was devoted for Guided Reading to increase students' reading in large classrooms, especially in English as a foreign language. I found that in smaller classrooms like IsiZulu and Xitsonga, students' participation in group discussion was much easier to be handled by teachers than in the other two large classes for Sepedi. The group discussions also improved oral language proficiency. Therefore, it is suggested that the South African Department of Basic Education needs to revisit time allocation for additional languages in schools, especially English which is considered as an international communicative language.

\section{Conclusion}

Based on the findings, there is a need to provide teachers' training in order to increase teachers' knowledge and skills for using Guided Reading in their classrooms and for selecting relevant levelled books for their students. Teachers need to be equipped with appropriate information of literacy policy that would provide more direction to reading instruction.

Teachers need to have enough literacy reading materials and a variety of children's levelled books in their classrooms and school library for all diverse learners. Regarding sufficient literacy materials in general, schools need to take responsibility for developing a reading programme for all children, including those identified as at risk in their classrooms. This would help to prevent high failure rates in Intermediate Phase and improve reading across the school curriculum.

Because lack of reading material and teachers training involve Department of Basic Education, this will need proper attention from the Ministry of Education to address these issues. In the meantime, the school library needs to be organised and labelled with an appropriate Guided Reading level system, which would assist students not to struggle as they find and read books of their interest. Because FP students were not encouraged to check out books from the library based on the stigma that they would not be responsible of taking care of books, teachers also need to train students to respect and care for books.
Teachers need to make Guided Reading instruction more fun by engaging them in the read-aloud and group discussion processes. They should model and encourage students to use think-aloud strategies as well as frequently practice vocabulary to increase students' comprehension and language proficiency, especially for smoother transition from native language to the English language.

\section{Acknowledgements Competing interests}

The authors declare that they have no financial or personal relationships which may have inappropriately influenced them in writing this article.

\section{Authors' contributions}

C.B.R. was the project leader and M.P.M. implemented the project design and performed calculations from observation data. Both the authors made equal conceptual contributions.

\section{References}

Avalos, M., Plasencia, A., Chavez, C. \& Rascon, J., 2007, 'Modified guided reading: Gateway to english as a second language and literacy learning', The Reading Teacher 61(4), 318-329. http://dx.doi.org/10.1598/RT.61.4.4

Ford, M. \& Opitz, M., 2008, 'A national survey of guided reading practices: What we can learn from primary teachers', Literacy Research and Instruction 47(4), 309-331. learn from primary teachers', Literacy Research
$\mathrm{http}: / / \mathrm{dx}$.doi.org/10.1080/19388070802332895

Fountas, I.C. \& Pinnell, G.S., 1996, Guided reading: Good first teaching for all children, Heinemann, Portsmouth, $\mathrm{NH}$.

Heilman, A.W., Blair, T.R. \& Rupley, W.H., 2002, Principles and practices of teaching reading, 10th edn., Pearson Education, Inc, New Jersey.

Kruizinga, A. \& Nathanson, R., 2010, 'An evaluation of guided reading in three primary schools in the Western Cape', A Journal for Language Learning 26(2), 67-76.

National Institute of Child Health and Human Development. 2000, Report of the National Reading Panel. Teaching children to read: An evidence-based assessment of the scientific research literature on reading and its implications for reading instruction: Reports of the subgroup (NIH Publication No. 00-4754), US. Government Printing Office, Washington, DC.

Pressely, M., 2000, 'What should comprehension instruction be the instruction of?' in M.L. Kamil, P.B. Mosenthal, P.D. Pearson \& R. Barr (eds.), Handbook of reading research, vol. III, pp. 545-586, Lawrence Erlbaum Associates, Mahway, NJ.

South African Department of Education (DoE) 2007, Teaching reading in early grades: A teacher's handbook, Department of Education, Pretoria.

South African Department of Education (DoE) 2003, Revised national curriculum statement grades R-9 (schools), Teachers's guide for the development of learning programs, Foundation Phase, Department of Education, Pretoria.

\section{Literature cited}

Kipling, R., 1986, The elephant's child, Random House Children's Book, New York. Steptoe, J., 1993, Mufaro's beautiful daughters, HarpersCollins Publishers, New York. 


\section{Appendix 1 \\ Checklist for developing level reader}

\begin{tabular}{|c|c|c|c|c|c|}
\hline \multicolumn{6}{|l|}{ Developing Level } \\
\hline \multicolumn{2}{|l|}{ Student's name: } & \multicolumn{4}{|c|}{ Tests } \\
\hline Comprehension & & Date: & Date: & Date: & Date: \\
\hline $\begin{array}{l}\text { A. Ask: What is happening in this picture? How is } \\
\text { the different from picture } \\
\text { B. Ask } 2-3 \text { questions, e.g. What is the story } \\
\text { about? Why did it go? Tell me if this is true or } \\
\text { false: The elephant child was naughty. } \\
\text { Who is the main character in the story? }\end{array}$ & $\begin{array}{l}\text { 1. Can the student say what is happening in the picture and } \\
\text { compare pictures? } \\
\text { 2. Answers a factual and an inferential question about the text } \\
\text { 3. Answers True or false question about the text } \\
\text { 4. Can identify the main character in the text? }\end{array}$ & & & & \\
\hline $\begin{array}{l}\text { Point to } 2-3 \text { words. Ask: How many syllables are } \\
\text { there in this word? What word does it rhyme } \\
\text { with? Point to a word containing a 3-letter blend } \\
\text { and ask What this sound is? Point to a word asks } \\
\text { to search for a meaning. }\end{array}$ & $\begin{array}{l}\text { 1. Can break a word into syllables } \\
\text { 2. Can recognize rhyming words in the text } \\
\text { 3. Can read three letter blends } \\
\text { 4. Can write the words ending } \\
\text { 5. Can use dictionary to search word meaning }\end{array}$ & & & & \\
\hline $\begin{array}{l}\text { Sight Words: Show a word list. Have students } \\
\text { read 5-8 words. Or point to the sight words in } \\
\text { the texts }\end{array}$ & Can read most sight words & & & & \\
\hline \multicolumn{6}{|l|}{ Fluency } \\
\hline \multicolumn{6}{|l|}{ Reading habits } \\
\hline $\begin{array}{l}\text { Observe the student during Independent } \\
\text { Reading }\end{array}$ & $\begin{array}{l}\text { 1. Reads silently } \\
\text { 2. Reads instructions, invitations and other simple text types. }\end{array}$ & & & & \\
\hline
\end{tabular}

Summative Assessment List for Developing level reader

Name of a student

Reading Assessment Standards

Some attained

Many attained

Most attained

All attained

\section{Test 1 Date:}

Test 2 Date:

Test 3 Date:

Test 4 Date:

All skills have been attained. Promoted to 'transitional level'

Date:

Source: Adapted from Teaching Reading in Early Grades: A Teacher's Handbook, 2007, Department of Education, Pretoria 


\section{Appendix 2 \\ Checklist for transitional level reader}

Transitional Level

\begin{tabular}{|c|c|c|c|c|c|}
\hline \multirow{2}{*}{$\begin{array}{l}\text { Student's name: } \\
\text { Comprehension }\end{array}$} & & \multicolumn{4}{|c|}{ Tests } \\
\hline & & Date: & Date: & Date: & Date: \\
\hline $\begin{array}{l}\text { 1. Ask: Is this fiction or non-fiction? (true facts) } \\
\text { 2. Who is the main character in the story } \\
\text { 3. Ask What happened in the story? } \\
\text { 4. Ask: Why do you think he went to town? } \\
\text { 5. Did s/he see giraffe or lion? }\end{array}$ & $\begin{array}{l}\text { 1. Can read and identify fiction or non-fiction texts? } \\
\text { 2. Can identify main character and can describe plot very simple. } \\
\text { 3. Answers an inferential question about the text } \\
\text { 4. Answers a multiple-choice question about the text. }\end{array}$ & & & & \\
\hline
\end{tabular}

\section{Word recognition}

1. Ask: What is a suffix/prefix?

2. Can you point to words with a suffix/prefix?

3. Point to the sight words in the text for student to read.

4. Ask student to sort words and find its meaning of words.

Fluency

1.Give the student a familiar text:

Observe him/her read a few pages. If the student knows all

the words, provide a slightly more difficult text so that you

can observe how s/he tackles unknown words

1. Can recognize prefixes in the

2. Can read a range of common words

3. Can use word to create own sentences.

4. Can use dictionary to search meaning of words.

1. Reads familiar texts accurately

2. Read with appropriate expression

3. Pauses at the end of sentences

4. Uses some punctuation marks effectively

5. Self-corrects if something doesn't sound.

5. Self-corrects if something doesn't sound.
6 . Answer a multiple-choice question about the text

7. Reads with few hesitations
7. Rer

\section{Reading habits}

Observe the student during Independent Reading

1. Reads grade level texts independently

2. Reads silently for an extended time

3. Reads instructions, invitations and other simple text types.

4. Reads for pleasure

5. Can use a dictionary for meaning of words

\section{Summative Assessment List for transitional level reader}

Name of a student

Reading Assessment Standards

Some attained

Many attained

Most attained

All attained

\section{Test 1 Date:}

Test 2 Date:

Test 3 Date:

Test 4 Date:

All skills have been attained. Promoted to 'transitional level'

Date:

Source: Adapted from Teaching Reading in Early Grades: A Teacher's Handbook, 2007, Department of Education, Pretoria 


\section{Appendix 3 \\ Checklist for independent level reader}

\begin{tabular}{|c|c|c|c|c|c|}
\hline \multicolumn{6}{|l|}{ Independent Level } \\
\hline \multirow{2}{*}{$\begin{array}{l}\text { Student's name: } \\
\text { Comprehension }\end{array}$} & & \multicolumn{4}{|c|}{ Tests } \\
\hline & & Date: & Date: & Date: & Date: \\
\hline $\begin{array}{l}\text { 1. Ask: What type of text is this? } \\
\text { 2. What is happening in this illustration? } \\
\text { 3. What is the main idea in the text? } \\
\text { 3. Ask What happened in the story? } \\
\text { 4. Ask: Why did the boy run away? } \\
\text { 5. Ask: Did s/he see giraffe or lion or elephant? } \\
\text { 6. Ask: What do you think the author wants us to } \\
\text { feel? Why do you think so? }\end{array}$ & $\begin{array}{l}\text { 1. Can derive from text whether it is a: biography, story, newspaper } \\
\text { article, fiction or non-fiction? } \\
\text { 2. Can point out features such as headings and labels. } \\
\text { 3. Can say what is happening in a variety of illustrations e.g. maps, or } \\
\text { graphs } \\
\text { 4. Answers complex questions about the text including why questions. } \\
\text { 5. Answer multiple-choice question about the text. } \\
\text { 6. Can give choice about the ideas in the text and give good reason for } \\
\text { her/his answer. }\end{array}$ & & & & \\
\hline
\end{tabular}

\section{Word recognition}

Point to the common words in the text.

Can read a large range of common words on sight.

\section{Fluency}

1.Give a student a text at the correct level: Observe him/her read a few pages. If a student knows all the words, provide a slightly more difficult text so that you can observe how s/he tackles unknown words

1. Reads accurately

2 . Read fluently and at a good pace

3. Pauses at the end of sentences and responds to all punctuation

4. Self-corrects when it doesn't make sense.

6 . Reads with no hesitations

\section{Reading habits}

Observe the student during Independent Reading Give a student an unfamiliar text to read from for a few seconds

1. Reads unfamiliar text confidently

2. Reads silently for an extended time

3. Reads a range of text (e.g. newspapers, textbooks, non-fiction books).

4. Reads for pleasure

5. Can use a dictionary or other references for meaning of words without hesitation

\begin{tabular}{l}
\hline Summative Assessment List for independent level reader \\
$\begin{array}{l}\text { Name of a student } \\
\text { Reading Assessment Standards }\end{array}$ \\
\hline Test 1 Date: \\
Test 2 Date: \\
Test 3 Date: \\
Test 4 Date: \\
\hline All skills have been attained. Promoted to 'transitional level' \\
Date:
\end{tabular}

Source: Adapted from Teaching Reading in Early Grades: A Teacher's Handbook (2007), Department of Education, Pretoria 